\title{
KARAKTERISTIK FISIKOKIMIA DAN SENSORI BERAS ANALOG MULTIGRAIN BERPROTEIN TINGGI
}

\author{
[Physicochemical and Sensory Qualities of High Protein Multigrain Artificial Rice]
}

\author{
Ari Andika $^{1) \star}$, Feri Kusnandar ${ }^{2)}$, dan Slamet Budijanto ${ }^{2)}$ \\ 1) Program Studi Ilmu Pangan, Sekolah Pascasarjana, IPB University, Bogor \\ 2) Departemen Ilmu dan Teknologi Pangan, Fakultas Teknologi Pertanian, IPB University, Bogor
}

Diterima 9 Agustus 2020 / Disetujui 15 Juni 2021

\begin{abstract}
Several grains (green bean, red bean, soybean, corn, nuts, sesame, and millets) were processed to yield a high protein analogue rice. Red beans and green beans were soaked in water for six hours while soybean was boiled for 10 minutes and then peeled. Nuts were dried at $70^{\circ} \mathrm{C}$, ground, and sieved to pass 80 mesh. All grains were ground into powder except for sesame which was in whole seed. Four formulas of rice analogues were produced at a different level of millet (0-15\%), corn (35-50\%) with fixed level of red beans (10\%), soybeans (25\%), green beans (10\%), sesame (3\%), and glycerol monostearate (GMS) (2\%). The products were analyzed in terms of proximate composition, hardness, water absorption index, development ratio, cooking time, in vitro protein digestibility, amino acids composition, and protein digestibility-corrected amino acid score (PDCAAS). The four analogue rice formulas contained high level of protein and protein digestibility, but they did not fulfill the targeted complementation. The protein content of the analogue rice varied from 18.19 to $19.09 \%$ (wet based) with protein digestibility of $81.27-88.86 \%$. The most preferred formulas of the rice analogue was composed of corn $(40 \%)$, millet (10\%, red beans (10\%), soybeans (25\%), green beans (10\%), sesame (3\%), and GMS (2\%). It contained $42.48 \%$ of amino acids score and $36.53 \%$ of PDCAAS value.
\end{abstract}

Keywords: artificial rice, formulation, multigrain, protein quality

\begin{abstract}
ABSTRAK
Beberapa jenis biji-bijian (kacang merah, kacang hijau, kedelai, jagung, wijen dan jewawut) diolah dengan tujuan untuk mendapatkan beras analog tinggi protein. Kacang merah dan kacang hijau direndam selama 6 jam, sedangkan kedelai direbus selama 10 menit dan dikupas kulitnya. Kacang-kacangan dikeringkan selama 7 jam pada suhu $70^{\circ} \mathrm{C}$, ditepungkan dan diayak sehingga diperoleh tepung ukuran 80 mesh. Biji-bijian langsung ditepungkan tanpa perlakuan kecuali wijen yang dicampurkan utuh. Empat formulasi beras analog divariasikan dengan persentase jewawut (0-15\%), jagung (35-50\%), kacang merah $10 \%$, kedelai $25 \%$, kacang hijau $10 \%$, wijen $3 \%$ dan gliserol monostearat (GMS) $2 \%$. Beras analog dianalisis proksimat, kekerasan, indeks absorpsi air, rasio pengembangan, waktu pemasakan, daya cerna protein in vitro, kadar asam amino dan potein digestibility-corrected amino acid score (PDCAAS). Seluruh formula beras analog yang dihasilkanmemiliki kandungan protein dan daya cerna yang tinggi, meskipun kandungan asam aminonya belum mencapai target komplementasi. Beras analog yang dihasilkan memiliki kadar protein 18,19-19,09\% (basis basah) dengan daya cerna protein $81,27-88,86 \%$. Formula beras analog yang paling disukai adalah dari campuran jagung (40\%), jewawut (10\%), kacang merah (10\%), kedelai $(20 \%)$, kacang hijau $(10 \%)$, wijen $(3 \%)$ dan GMS $(2 \%)$. Formula ini memiliki skor asam amino $42,48 \%$ dan nilai PDCAAS $36,53 \%$.
\end{abstract}

Kata kunci: beras analog, formulasi, kualitas protein, multigrain

*Penulis Korespondesnsi:

E-mail: ariandikaalbas@gmail.com 


\section{PENDAHULUAN}

Protein diperlukan untuk pertumbuhan, pemeliharaan, pertahanan dan perbaikan jaringan tubuh manusia (Gehring et al., 2020). Kecukupan asupan protein sangat penting dalam diet seseorang untuk dipenuhi sesuai kebutuhannya. Recommended dailly allowance (RDA) protein per hari secara umum adalah $0,8 \mathrm{~g} / \mathrm{kg}$ berat badan. Kelompok orang dengan aktivitas fisik yang lebih tinggi seperti atlet, kebutuhan proteinnya lebih tinggi dibandingkan orang dengan aktivitas fisik normal (Di Girolamo et al., 2017).

Protein nabati memiliki kualitas protein yang kurang baik, karena mengandung asam amino esensial tertentu dalam jumlah terbatas (asam amino pembatas) dan daya cerna proteinnya yang rendah (Astawan et al., 2015). Rasio asam amino protein nabati dapat diperbaiki dengan mencampurkan beberapa jenis bahan pangan, seperti mencampur serealia yang biasanya kaya metionin dan rendah lisin dengan kacang-kacangan yang rendah metionin namun kaya lisin, sehingga dihasilkan komposisi asam amino yang lebih lengkap atau saling melengkapi (komplementasi). Salah satu produk olahan yang dapat dijadikan sebagai model pangan komplementasi adalah beras analog. Proses pembuatan beras analog memungkinkan untuk memodifikasi kandungan gizinya (Noviasari et al., 2015), termasuk untuk diatur kandungan proteinnya.

Penelitian beras analog telah dikembangkan sebelumnya dengan menggunakan teknologi ekstrusi dan memanfaatkan bahan non beras seperti sorgum (Budijanto dan Yuliyanti, 2012), campuran jagung, sorgum dan sagu aren (Budijanto et al., 2013), jagung putih dan sagu (Noviasari et al., 2013), campuran jagung putih, sorgum dan kedelai (Noviasari et al., 2015), campuran jagung, kedelai, pati sagu (Anindita et al., 2020). Pemanfaatan kacang-kacangan dalam pembuatan beras analog sebelumnya sangat mendukung peningkatan kandungan protein produk, terutama kacang kedelai.

Jewawut, jagung, wijen dan kacang-kacangan mempunyai prospek untuk digunakan sebagai bahan pembuatan beras analog dalam bentuk komposit untuk menghasilkan produk dengan kandungan asam amino esensial yang lebih baik. Jewawut dikenal kaya metionin dan sistein, sedangkan kacang-kacangan mengandung lisin yang tinggi namun metionin yang rendah (Amadou et al., 2013; Anitha et al., 2019). Saat ini, penggunaan jewawut dalam produk ekstrusi masih terbatas. Penelitian ini bertujuan untuk mengembangkan beras analog yang dibuat dari campuran biji-bijian untuk meningkatkan kandungan dan mutu proteinnya. Perbandingan yang tepat antara jagung dan jewawut, serta biji-bijian dan kacang-kacangan lainnya (kacang merah, kacang hijau, kedelai, jagung, wijen) untuk menghasilkan beras analog dengan mutu protein dan mutu fisik yang diinginkan.

\section{BAHAN DAN METODE}

\section{Bahan}

Bahan yang digunakan adalah kacang merah dan kacang hijau dari pasar Suryakencana Bogor, kedelai non GMO (Rumah Tempe Indonesia, Bogor), jagung dari PT. Kediri Corn Mill (Kediri), jewawut putih merek Vita, wijen dari pasar Anyar Bogor, gliserol monostearat (GMS) dari PT Lautan Luas, enzim pepsin (Merck, Jerman) dan pankreatin (Sigma, Jerman).

\section{Persiapan bahan baku}

Kedelai direbus selama 10 menit kemudian didiamkan hingga dingin dan dilepaskan kulitnya dengan remasan tangan. Kedelai direbus dan dikupas kulitnya dengan tujuan untuk mengurangi enzim lipoksigenase yang bertanggung jawab pada pembentukan bau langu pada tepung dan produk akhir (Anindita et al., 2020), sedangkan kacang merah dan kacang hijau hanya direndam selama 12 jam untuk melunakkan teksturnya (Mohamed et al., 2011). Kacang-kacangan tersebut kemudian dikeringkan dengan pengering kabinet selama 7 jam pada suhu $70^{\circ} \mathrm{C}$ dan ditepungkan dengan menggunakan pin disc mill. Tepung jagung dan jewawut sosoh ditepungkan dengan menggunakan pin disc mill tanpa perlakuan awal (Kharat et al., 2019), sedangkan wijen langsung dicampur ketika pembuatan adonan (Sukarno et al., 2020). Semua tepung diayak dengan ukuran 80 mesh dan dikemas dengan plastik.

\section{Formulasi dan komplementasi}

Formulasi ditentukan berdasarkan dengan mengacu pada Anindita et al. (2020) dan komplementasi dihitung dengan menggunakan microsoft excel 2013 (Tabel 1). Kedelai merupakan bagian paling penting untuk meningkatkan kandungan protein, namun penambahan kedelai terbatas pada taraf $25 \%$ karena pengaruh tingkat penerimaan panelis (Anindita et al., 2020). Penambahan kacang hijau dan kacang merah mampu meningkatkan mutu sensori, namun mengandung metionin yang rendah sehingga penambahan pada penelitian ini dibatasi hanya 10\% (Kanetro et al., 2017) dan (Fauziyah et al., 2017). Jagung dan jewawut divariasikan karena penerimaan sensorinya yang baik dan merupakan faktor penentu komplementasi (kandungan metionin dan lisin mendekati angka rekomendasi). Wijen yang dianjurkan oleh Sukarno et al. (2020) pada produk sereal ekstrusi adalah kurang dari 5\% untuk menghindari produk dengan aftertaste pahit yang kurang disukai panelis. 
Perhitungan komplementasi dilakukan dengan mengumpulkan data pustaka kandungan asam amino esensial ke enam bahan baku yang digunakan dari katalog FAO (1981). Data kemudian dikombinasikan menggunakan microsoft excel 2013 untuk mendapatkan beberapa kemungkinan formula dengan jumlah asam amino yang lengkap (Tabel 2).

\section{Pembuatan beras analog (Budijanto dan Yuliyanti, 2012 dengan modifikasi)}

Tahapan proses pembuatan beras analog adalah sebagai berikut: persiapan bahan baku dan penimbangan bahan; pencampuran bahan kering selama 5-10 menit dengan penambahan $2 \%$ GMS, lalu penambahan air secara perlahan sebanyak $50 \%$ dan pencampuran selama 5 menit; pengaturan ekstruder pada suhu $95^{\circ} \mathrm{C}$ dengan kecepatan cutter
$25 \mathrm{~Hz}$ dan kecepatan auger $35 \mathrm{~Hz}$; dan ekstrusi dengan menggunakan mesin ekstruder tipe ulir ganda (Twin Screw Bex 225-6, Berto Industries, Indonesia) dengan cetakan menyerupai butiran beras; dan (5) pengeringan ekstrudat pada $60^{\circ} \mathrm{C}$ selama 3 jam dengan oven pengering (Tea Drier Oven, Terada Seisakusho, Jepang). Produk beras analog kemudian dikemas dengan kemasan plastik dan disimpan dalam lemari pendingin (Gambar 1).

\section{Analisis komposisi kimia}

Sampel beras analog dianalisis kandungan proksimatnya dengan mengacu pada metode AOAC (2012) (dinyatakan dalam persen basis basah), analisis serat kasar (Busuttil-Griffin et al., 2015), analisis karbohidrat by difference dan perhitungan total kalori (Lieberman et al., 2020).

Tabel 1. Formulasi perlakuan beras analog (\%)

\begin{tabular}{lccccccc}
\hline Formula & Kacang Merah & Kedelai & Kacang Hijau & Jewawut & Jagung & Wijen & GMS \\
\hline F1 & 10 & 25 & 10 & 0 & 50 & 3 & 2 \\
F2 & 10 & 25 & 10 & 5 & 45 & 3 & 2 \\
F3 & 10 & 25 & 10 & 10 & 40 & 3 & 2 \\
F4 & 10 & 25 & 10 & 15 & 35 & 3 & 2 \\
\hline
\end{tabular}

Keterangan: Persentase kacang-kacangan dan biji-bijian 98\% ditambahkan GMS 2\%

Tabel 2. Asam amino esensial dalam satuan $\mathrm{mg} / \mathrm{g}$ protein

\begin{tabular}{lcccccc}
\hline \multicolumn{1}{c}{ Asam Amino } & Kacang Merah & Kedelai & Kacang Hijau & Jewawut & Jagung & Wijen \\
\hline Ile & 41,92 & 49,74 & 35,68 & 40,89 & 36,80 & 42,64 \\
Leu & 76,16 & 85,11 & 70,56 & 95,53 & 125,28 & 79,06 \\
Lys & 72,00 & 69,88 & 80,64 & 34,19 & 26,72 & 32,26 \\
Met dan Cys & 19,04 & 28,37 & 12,32 & 48,24 & 34,72 & 54,53 \\
Phe dan Tyr & 77,44 & 88,44 & 73,92 & 80,51 & 87,04 & 89,06 \\
Thr & 39,68 & 42,21 & 33,44 & 38,50 & 36,00 & 42,08 \\
Trp & 10,08 & 13,66 & 8,00 & 19,49 & 6,08 & 15,85 \\
Val & 45,92 & 52,54 & 41,44 & 55,11 & 48,48 & 54,34 \\
\hline Total asam amino & 382,24 & 429,95 & 356 & 412,46 & 401,12 & 409,82 \\
\hline Konversi bahan & 6,25 & 5,71 & 6,25 & 6,26 & 6,25 & 5,3 \\
\hline
\end{tabular}

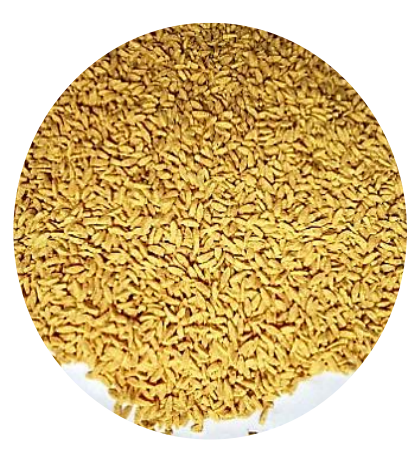

F1

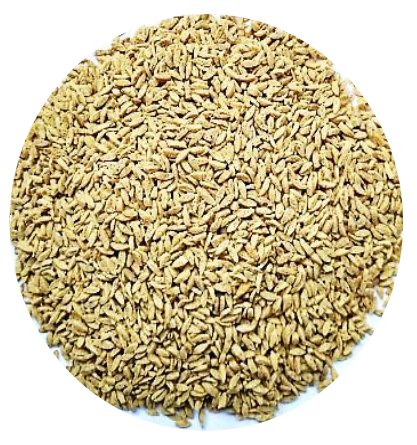

F2

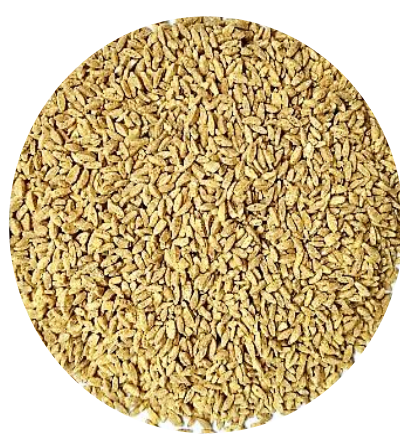

F3

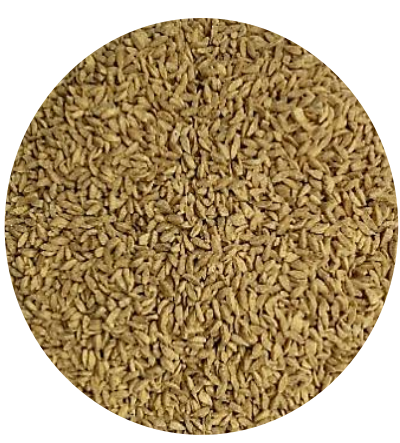

F4

Gambar 1. Sampel beras analog 
Kekerasan beras analog (Budi et al., 2017)

Sampel beras analog diukur kekerasannya dengan menggunakan alat hardness tester (Kiya Seisaku Shd Ltd, Kawagoe, Saitama, Jepang). Setiap sampel diukur sebanyak 30 kali dan angka yang ditunjukkan oleh jarum dihitung nilai rataratanya.

\section{Indeks absorpsi air (Lee et al., 2012)}

Sampel beras analog ditepungkan, kemudian ditimbang sebanyak $1 \mathrm{~g}$. Sampel tepung dilarutkan dengan $10 \mathrm{~mL}$ air destilata dalam tabung sentrifusi yang telah ditimbang sebelumnya, dikocok selama 10 menit dan disentrifusi (centrifuge Eppendorf 5810 $\mathrm{R}$, Jerman) pada $3000 \mathrm{rpm}$ selama 30 menit. Supernatan dibuang dan tabung berisi gel ditimbang. Indeks absorpsi air dihitung sebagai persentase dari berat gel $(\mathrm{g})$ terhadap berat sampel $(g / g)$.

\section{Indeks pengembangan (Behzadfar et al., 2015 dengan modifikasi)}

Sampel beras analog yang diukur adalah yang memiliki bentuk bulat panjang (Gambar 1). Diameter beras analog diukur dengan menggunakan jangka sorong (Mitutoyo, Jepang). Hasil pengukuran kemudian dibandingkan dengan diameter die (cetakan). Indeks pengembangan dinyatakan sebagai persentase dari rasio diameter silinder sampel terhadap diameter die (cetakan).

\section{Waktu pemasakan (Noviasari et al., 2013)}

Air direbus terlebih dahulu menggunakan penanak nasi/rice cooker (Cosmos CRJ-6601, Indonesia). Sebanyak $100 \mathrm{~g}$ sampel beras analog dimasukan (rasio air dan beras $=1: 1$ ). Proses pemasakan ini dilakukan berbeda dengan pemasakan beras biasa karena beras analog sudah mengalami perlakuan pemanasan selama proses ekstrusi dan pengeringan di dalam oven. Lamanya waktu pemasakan dihitung dengan menggunakan pencatat waktu (stopwatch) sejak beras analog dimasukkan hingga matang (lampu indikator cook menjadi warm).

\section{Uji organoleptik (Meilgaard et al., 1999 dengan modifikasi)}

Uji organoleptik dengan metode uji hedonik menggunakan nasi analog $( \pm 4 \mathrm{~g})$ yang disajikan dengan kode sampel acak terhadap 40 panelis tidak terlatih dengan atribut rasa, warna, aroma dan tekstur. Panelis direkrut dari mahasiswa Institut Pertanian Bogor berusia 15-40 tahun. Uji dilakukan dengan modifikasi pada kondisi khusus selama pandemi covid-19. Sampel diantar langsung ke tempat masing-masing panelis (home use test) yang telah disurvei sebelumnya dengan mengisi google form dengan kriteria panelis adalah sehat, tidak alergi kacang-kacangan dan tidak buta warna. Uji organoleptik dilakukan dua kali ulangan dengan setiap kali ulangan terdiri dari empat formulasi sampel yang sudah diberi kode acak. Panelis diminta untuk menilai sampel berdasarkan tingkat kesukaan dengan skor kesukaan menggunakan skala 5, yaitu dari skor 1 (sangat tidak suka), 2 (agak tidak suka), 3 (agak suka), 4 (suka), dan 5 (sangat suka).

\section{Analisis asam amino}

Sampel beras analog dianalisis kompossi asam aminonya dengan menggunakan UPLC (SIG, 2013) di laboratorium Sarawanti Indo Genetech, Bogor. Sampel $(0,1 \mathrm{~g})$ dihidrolisis dengan $5 \mathrm{~mL} \mathrm{HCl} 6 \mathrm{~N}$ pada $110^{\circ} \mathrm{C}$ selama 22 jam, kemudian dipindahkan ke dalam labu $50 \mathrm{~mL}$ dan disaring dengan filter 0,45 $\mu \mathrm{m}$. Filtrat $(500 \mu \mathrm{L})$ ditambahkan dengan $40 \mu \mathrm{m}$ larutan standar internal AABA dan $460 \mu \mathrm{L}$ aquabides. Larutan tersebut kemudian dipipet sebanyak $10 \mu \mathrm{L}$, ditambahkan $70 \mu \mathrm{L}$ AccQ-Fluor Borat dan 20 $\mu \mathrm{L}$ reagen fluor $\mathrm{A}$. Larutan diinkubasi pada $55^{\circ} \mathrm{C}$ selama 10 menit kemudian filtrat diambil $1 \mu \mathrm{L}$ untuk disuntikkan ke dalam UPLC.

\section{Analisis daya cerna protein secara in vitro (Almeida et al., 2015)}

Sampel $(1-2 \mathrm{~g})$ ditambahkan $15 \mathrm{~mL}$ larutan enzim $\mathrm{A}(1,5 \mathrm{mg}$ enzim pepsin dalam $15 \mathrm{~mL} \mathrm{HCl} 0,1$ N) dan dimasukan ke dalam shaker water bath (Daihan Labtech, Korea) pada $37^{\circ} \mathrm{C}$ selama tiga jam, lalu dinetralkan $(\mathrm{pH} 7,0)$ dan ditambahkan 7,5 $\mathrm{mL}$ larutan enzim B (4 mg enzim pankreatin dalam $7,5 \mathrm{~mL}$ bufer fosfat $0,2 \mathrm{M} \mathrm{pH} \mathrm{8,0),} \mathrm{dan} \mathrm{dimasukkan}$ kembali ke dalam shaker water bath $\left(37^{\circ} \mathrm{C}\right.$ selama 24 jam). Sampel kemudian di-sentrifusi, dicuci, disaring dan residunya dikeringkan di dalam oven $105^{\circ} \mathrm{C}$ selama 2 jam. Padatan dianalisis kandungan proteinnya dengan metode Kjeldahl (AOAC, 2012). Kadar protein yang diperoleh adalah sisa protein yang tidak tercerna oleh enzim pepsin dan pankreatin.

\section{Analisis kualitas protein metode PDCAAS (Almeida et al., 2015)}

Protein digestibility-corrected amino acid score (PDCAAS) merupakan hasil perkalian nilai daya cerna protein dengan skor asam amino esensial pembatas (skor asam amino terendah).

\section{Pengolahan data}

Penelitian menggunakan rancangan acak lengkap dengan dua kali ulangan dan sampel dianalisis duplo tiap perlakuan untuk melihat perbedaan antara keempat formula beras analog. Analisis statistik dilakukan dengan ANOVA dan uji lanjut dengan Tukey HSD Test dengan menggunakan software minitab versi 16.2.1 (tahun 2012) pada taraf nyata $5 \%$. 


\section{HASIL DAN PEMBAHASAN}

\section{Komposisi kimia}

Bahan baku utama pada beras analog sangat mempengaruhi komposisi proksimat beras analog yang dihasilkan. Tabel 3 menyajikan komposisi kimia bahan baku yang digunakan dalam penelitian ini, sedangkan Tabel 4 menyajikan komposisi kimia beras analog yang dihasilkan. Komposisi kimia beras analog (basis basah) terdiri dari kadar abu $(2,59-3,24 \%)$, protein $(17,19-19,09 \%)$, lemak $(8,47-$ $9,30 \%)$ dan serat kasar $(0,99-1,69 \%)$. Ke empat formulasi beras analog tersebut memiliki komposisi kimia yang lebih tinggi jika dibandingkan dengan kandungan kimia pada beras padi yang memiliki kadar abu $(0,8 \%)$, kadar protein $(8,4 \%)$, lemak $(1,7 \%)$ dan serat kasar $(0,2 \%)$. Kadar air $(4,17-$ $5,60 \%)$ dan kadar karbohidrat $(63,77-66,57 \%)$ beras analog yang dihasilkan lebih rendah jika dibandingkan dengan beras padi (Tabel 4).

Perlakuan campuran bahan menyebabkan perubahan kandungan zat gizi, terutama protein yang meningkat secara nyata dengan penambahan jewawut. Penambahan jewawut mendukung kenaikan kandungan protein pada beras analog walaupun dalam sedikit. Beras analog tanpa penambahan jewawut (F1) memiliki kandungan protein $17,19 \%$. Dibandingkan beras analog tanpa jewawut (F1), penambahan jewawut meningkatkan 1,0\% kandungan protein (5\% jewawut, F2), 1,76\% (10\% jewawut, F3) dan 1,90\% (15\% jewawut, F4). Kandungan protein ini lebih tinggi dibandingkan beras padi (8,4\%). Menurut European Commission (2012) tentang nutrition claims, makanan dapat diklaim sebagai sumber protein jika minimal mengandung $12 \%$ dari nilai energi makanan tersebut disediakan oleh protein. Beras analog multigrain menyediakan energi dari protein sebesar 16,61-18,62\% (Tabel 4), sehingga keempat formula beras analog multigrain dapat memenuhi persyaratan klaim sebagai sumber protein.

Penambahan jewawut meningkatkan kandungan serat kasar produk dari $0,99 \%$ (F1) menjadi $1,08 \%$ (F2), 1,39\% (F3) dan 1,69\% (F4) (Tabel 4). Hal yang berbeda terjadi pada kandungan karbohidrat yang menurun seiring dengan banyaknya jumlah jewawut yang ditambahkan. Beras analog F1 memiliki kandungan karbohidrat $65,27 \%$. Kandungan karbohidrat cenderung menurun dengan penambahan jewawut, yaitu, yaitu beras analog $\mathrm{F} 2$ (66,57\%), F3 (64,34\%) dan F4 (63,77\%) (Tabel 3). Berdasarkan penelitian Patil et al. (2015), flakes (sereal) berbasis jewawut mengandung serat lebih tinggi dibandingkan dengan flakes (sereal) berbasis tepung beras konvensional.

Perbandingan penambahan bahan ke dalam formulasi beras analog menyebabkan perbedaan pada kandungan protein dan serat, namun tidak menyebabkan perbedaan pada kandungan air, abu, lemak, karbohidrat, kalori dan energi protein (Tabel 4).

\section{Mutu fisik}

Beras analog multigrain yang diuji fisik adalah beras yang telah dikeringkan dalam oven $70^{\circ} \mathrm{C}$ selama 3 jam. Hasil analisis mutu fisik, kekerasan (hardness), penyerapan air (water absorption index), rasio pengembangan dan waktu pemasakan disajikan pada Tabel 5. Kekerasan adalah uji yang dilakukan untuk mengukur kekuatan biji beras analog terhadap gaya tekan yang diterima, sedangkan rasio pengembangan merupakan ukuran pengembangan yang terjadi jika ekstrudat dibandingkan dengan besarnya lubang die.

Tabel 3. Daftar kandungan kimia kacang-kacangan (\%)

\begin{tabular}{lcccccc}
\hline \multicolumn{1}{c}{ Jenis Kacang } & Protein & Lemak & Karbohidrat & Air & Abu & Serat \\
\hline Kacang merah & 22,00 & 0,25 & 66,45 & 11,75 & 3,83 & 2,40 \\
Kedelai & 38,00 & 16,12 & 38,19 & 10,77 & 3.49 & 2.90 \\
Kacang hijau & 22,90 & 1,50 & 56,80 & 15,50 & 3,30 & 7,50 \\
Jagung Harapan & 6,50 & 5,10 & 76,20 & 11,30 & 1,20 & 2,60 \\
Jewawut & 12,90 & 4,80 & 67,10 & 11,90 & 2,80 & 7,40 \\
Wijen & 18,00 & 51,10 & 18,10 & 5,80 & 5,60 & 3,60 \\
\hline
\end{tabular}

Keterangan: Sumber Kemenkes (2018)

Tabel 4. Komposisi kimia beras analog multigrain

\begin{tabular}{|c|c|c|c|c|c|c|c|c|}
\hline \multirow{2}{*}{ Formula } & \multicolumn{6}{|c|}{ Komposisi Kimia (\%) } & \multirow{2}{*}{$\begin{array}{l}\text { Kalori } \\
\text { (kkal) }\end{array}$} & \multirow{2}{*}{$\begin{array}{c}\text { Energi Protein } \\
(\%)\end{array}$} \\
\hline & Air & Abu & Protein & Lemak & Karbohidrat & Serat & & \\
\hline$\overline{\mathrm{F} 1}$ & $5,60 \pm 0,78$ & $, 64 \pm 0,31$ & $17,19 \pm 0,30^{6}$ & $9,30 \pm 0,09$ & $65,27 \pm 0,68$ & $0,99 \pm 0,13^{b}$ & $413 \pm 2,29$ & $16,61 \pm 0,36$ \\
\hline $\mathrm{F} 2$ & $4,17 \pm 1,48$ & $2,59 \pm 0$ & $9 \pm 0,59^{\mathrm{ab}}$ & $8,47=$ & & $1,08 \pm 0,08^{b}$ & 0 & \\
\hline F3 & $4,91 \pm 0,67$ & $3,24 \pm 0,49$ & $18,95 \pm 0,10^{\mathrm{a}}$ & $8,56 \pm 0,22$ & 64 & $1,39 \pm 0,20^{a b}$ & 1 & \\
\hline $\mathrm{F} 4$ & $5,60 \pm 0,38$ & $2,61 \pm 0,18$ & $19,09 \pm 0,24^{a}$ & $8,93 \pm 0,46$ & $63,77 \pm 1,26$ & $1,69 \pm 0,08^{a}$ &, 08 & $18,62 \pm 0,12$ \\
\hline BGM & 12 & 0,8 & 8,4 & 1,7 & 77,1 & 0,2 & 357,30 & 9,40 \\
\hline
\end{tabular}

Keterangan: BGM= Beras giling mentah (Kemenkes, 2018); Kalori= protein dikali 4+karbohidrat dikali 4+ lemak dikali 9 
Tabel 5. Mutu fisik beras analog multigrain

\begin{tabular}{lcccc}
\hline Formula & Kekerasan $(\mathrm{Kg})$ & Daya serap air $(\mathrm{g} / \mathrm{g})$ & $\begin{array}{c}\text { Rasio } \\
\text { Pengembangan (\%) }\end{array}$ & $\begin{array}{c}\text { Waktu Pemasakan } \\
\text { (Menit) }\end{array}$ \\
\hline F1 & $1,56 \pm 0,32^{\mathrm{a}}$ & $3,08 \pm 0,02^{\mathrm{b}}$ & $103,38 \pm 0,18$ & $3,74 \pm 0,34$ \\
F2 & $1,05 \pm 0,04^{\mathrm{ab}}$ & $3,15 \pm 0,04^{\mathrm{b}}$ & $100,63 \pm 0,18$ & $3,79 \pm 0,15$ \\
F3 & $0,78 \pm 0,05^{\mathrm{ab}}$ & $3,28 \pm 0,18^{\mathrm{ab}}$ & $101,50 \pm 0,00$ & $3,86 \pm 0,07$ \\
F4 & $0,56 \pm 0,27^{\mathrm{b}}$ & $3,64 \pm 0,08^{\mathrm{a}}$ & $94,13 \pm 1,59$ & $3,87 \pm 0,13$ \\
\hline
\end{tabular}

Keterangan: Nilai merupakan rata-rata \pm standar deviasi dengan huruf yang berbeda pada satu kolom menunjukkan berbeda nyata $(P<0,05)$ dengan uji berbeda nyata Tukey

Penambahan jewawut dengan pengurangan persentase jagung mampu menurunkan kekerasan produk secara nyata $(P<0,05)$. F1 memiliki kekerasan sebesar $1,56 \mathrm{kgf}$, yang kemudian menurun menjadi 1,05 kgf pada F2, 0,78 kgf pada F3 dan $0,56 \mathrm{kgf}$ pada F4. Penurunan tingkat kekerasan tersebut sesuai dengan penelitian Karouw (2016) pada produk ekstrusi tepung jagung, beras dan konsentrat protein krim kelapa. Rasio pengembangan juga mengalami penurunan, namun tidak berbeda nyata antara rasio pengembangan, yaitu pada $\mathrm{F} 1$ $(103,38 \%)$, F2 $(100,63 \%)$, F3 (101,50\%) dan F4 $(94,13 \%)$. Penurunan kekerasan dan rasio pengembangan ini dipengaruhi oleh kandungan amilosa dan amilopektin dari jagung (Budi et al., 2017). Menurut Rincón-Londoño et al. (2016) dan Suarni et al. (2013) pati jagung mengandung amilosa $25-30 \%$ dan amilopektin 66-75\%. Amilosa berpengaruh terhadap peningkatan kekerasan, sedang amilopektin berpengaruh terhadap peningkatan rasio pengembangan suatu produk. Hal tersebut menunjukkan, berkurangnya persentase jagung dalam formulasi mengakibatkan semakin menurunnya tingkat kekerasan dan rasio pengembangan.

Daya serap air mengindikasikan kemampuan beras analog dalam menyerap air. Penambahan tepung jewawut ke dalam formulasi beras analog mampu meningkatkan daya serap air secara nyata $(P<0,05)$ dari $3,08 \mathrm{~g} / \mathrm{g}$ pada $\mathrm{F} 1$ menjadi $3,15 \mathrm{~g} / \mathrm{g}$ pada F2, kemudian meningkat menjadi $3,28 \mathrm{~g} / \mathrm{g}$ pada F3 dan 3,64 g/g pada 4. Daya serap air cenderung meningkat dengan semakin tingginya tepung jewawut yang ditambahkan, sebagai pengaruh dari serat kasar dan amilosa. Penyerapan air pada granula beras analog sangat didukung oleh kandungan serat kasar dan amilosa yang tinggi, sedangkan kadar protein dan lemak yang tinggi dapat berpengaruh sebaliknya (menurunkan absorbsi air). Protein dan lemak dapat menutupi partikel pati, sehingga penyerapan air pada produk menjadi terhambat. Proses ekstrusi diduga mempengaruhi sifat fungsional protein (ketersedian grup hidrofilik), yang berpengaruh pada kapasitas pengikatan yang berkaitan dengan pembentukan ikatan hidrogen antara air dan gugus polar dari protein (Suarni et al., 2013).

Proses pemasakan beras analog berbeda dengan beras padi pada umumnya, karena beras analog merupakan beras yang sudah terlebih dahulu mengalami perlakuan panas selama proses ekstrusi dan pengeringan ekstrudat di dalam oven. Selain itu, beras analog juga mudah hancur (kurang kokoh) jika dibandingkan dengan beras padi. Waktu pemasakan beras analog cenderung lebih cepat dibandingkan dengan beras padi. Uji lama pemasakan pada $100 \mathrm{~g}$ beras padi IR-64 menunjukkan waktu pemasakan selama \pm 16 menit (Wibawa et al., 2020). Waktu pemasakan beras analog pada penelitian ini hampir sama untuk keempat formula, yaitu berkisar antara 3,74-3,87 menit.

\section{Mutu organolpetik}

Penerimaan panelis terhadap warna dan tekstur menunjukkan perbedaan yang nyata $(P<0,05)$ antara keempat formula (Tabel 6). Hasil analisis menunjukkan bahwa tidak ada pengaruh nyata $(P>0,05)$ dari perbandingan tepung jewawut dan jagung yang ditambahkan terhadap tingkat kesukaan aroma nasi. Noviasari et al. (2013) menunjukkan bahwa peningkatan substitusi tepung jagung putih dalam pembuatan beras analog juga tidak berpengaruh nyata terhadap kesukaan aroma nasi analog.

Hasil pengujian sensori warna menunjukkan bahwa panelis lebih menyukai nasi analog dengan persentase penambahan jagung yang lebih besar. Nasi dari beras analog F1 lebih disukai dibandingkan nasi analog dengan F2, F3, dan F4. Penambahan jewawut dengan berkurangnya porsi jagung menyebabkan warna produk yang dihasilkan lebih kecokelatan. Hal ini karena jagung memiliki warna kuning cerah, sedangkan jewawut memiliki warna cokelat keemasan yang lebih gelap. Warna beras yang cerah lebih disukai panelis karena persepsi masyarakat tentang beras padi yang biasanya dimakan berwarna putih. Warna beras analog yang dihasilkan juga disebabkan oleh bahan baku kacang merah dan kacang hijau yang tidak dikupas, sehingga warna beras analog menjadi sedikit kusam dan gelap.

Tingkat kesukaan terhadap rasa nasi analog dengan perbandingan jumlah jewawut dan jagung menunjukkan tidak berpengaruh nyata terhadap kesukaan panelis, yaitu antara agak suka hingga suka (skor 3,10-3,93), namun secara umum rasa dari nasi analog masih dapat diterima oleh panelis. 
Tabel 6. Mutu sensori beras analog multigrain

\begin{tabular}{lccccc}
\hline \multirow{2}{*}{ Nasi Analog } & \multicolumn{5}{c}{ Skor Kesukaan } \\
\cline { 2 - 6 } & Aroma & Warna & Rasa & Tekstur & Keseluruhan \\
\hline F1 & $3,17 \pm 0,02$ & $4,15 \pm 0,04^{\mathrm{a}}$ & $3,10 \pm 0,02^{\mathrm{b}}$ & $3,22 \pm 0,13^{\mathrm{b}}$ & $3,38 \pm 0,07^{\mathrm{c}}$ \\
F2 & $3,16 \pm 0,07$ & $3,79 \pm 0,13^{\mathrm{b}}$ & $3,49 \pm 0,11^{\mathrm{ab}}$ & $3,43 \pm 0,07^{\mathrm{ab}}$ & $3,62 \pm 0,04^{\mathrm{b}}$ \\
F3 & $3,29 \pm 0,02$ & $3,53 \pm 0,04^{\mathrm{bc}}$ & $3,93 \pm 0,39^{\mathrm{a}}$ & $3,65 \pm 0,09^{\mathrm{a}}$ & $3,94 \pm 0,08^{\mathrm{a}}$ \\
F4 & $3,15 \pm 0,05$ & $3,37 \pm 0,01^{\mathrm{c}}$ & $3,13 \pm 0,16^{\mathrm{b}}$ & $3,24 \pm 0,00^{\mathrm{b}}$ & $3,12 \pm 0,04^{\mathrm{a}}$ \\
\hline
\end{tabular}

Keterangan: Nilai merupakan rata-rata \pm standar deviasi dengan huruf yang berbeda pada satu kolom menunjukkan berbeda nyata $(P<0,05)$ dengan uji beda nyata Tukey

Hasil uji ANOVA tekstur menunjukkan bahwa terdapat pengaruh yang nyata $(P<0,05)$ dari jumlah tepung jagung dan jewawut yang ditambahkan terhadap tingkat kesukaan tekstur. Penelitian Fitriani dan Astuti (2013) menunjukkan bahwa peningkatan substitusi tepung jagung juga berpengaruh nyata $(P<0,05)$ terhadap tekstur kekenyalan dan kelengketan produk nasi instan.

\section{Daya cerna protein}

Daya cerna protein tergantung pada faktor internal maupun eksternal. Faktor internal termasuk profil asam amino dan struktur protein. Faktor eksternal meliputi lingkungan $(\mathrm{pH}$, suhu, ionik, dan faktor antinutrisi) dan perlakuan (pemanasan, perendaman, fermentasi dan germinasi) (Impa et al, 2019). Daya cerna protein pada umumnya mendapatkan manfaat dari denaturasi pada suhu tinggi, tergantung pada tingkat perlakuan panas dan jenis protein. Protein dapat mengalami kehilangan struktur yang terlipat erat sehingga memberi akses yang lebih baik bagi enzim terhadap rantai peptida.

Daya cerna protein menunjukkan banyaknya protein yang dapat dicerna oleh tubuh atau banyaknya protein yang dapat dipotong ikatannya oleh enzim protease, sehingga dapat diperoleh asam-asam amino yang dapat langsung diserap oleh tubuh. Daya cerna protein keempat beras analog yang bervariasi, yaitu $88,86 \pm 0,17 \%(F 1)$,

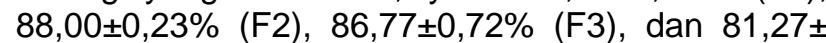
$1,38 \%$ (F4). Penambahan jewawut memberi pengaruh nyata $(P<0,05)$ terhadap menurunnya daya cerna protein (Gambar 2), meskipun mampu meningkatkan kadar kandungan proteinnya.

Penambahan jewawut dalam campuran serealia menurunkan daya cerna protein karena tingginya kandungan tanin pada jewawut $(0,04 \%$ $3,47 \%)$. Golongan tanin terkondensasi merupakan tanin yang sangat tahan terhadap hidrolisis dan mampu berikatan dengan protein sehingga mampu menurunkan daya cerna (Joye, 2019). Annor et al. (2017) juga menyatakan bahwa penambahan jewawut dalam campuran serealia dapat menyebabkan daya cerna protein yang menurun, yang dapat disebabkan oleh interaksi hidrofobik antar protein.

Penambahan jewawut berpengaruh terhadap tingginya kandungan serat kasar, semakin tinggi kandungan serat kasar maka akan semakin rendah daya cerna suatu makanan, karena dinding-dinding sel bahan tersebut lebih tebal dan tidak mudah ditembus oleh enzim pencernaan sehingga semakin cepat makanan tersebut masuk ke dalam saluran pencernaan dan memberikan sedikit waktu agar zat gizi dapat dicerna secara menyeluruh (Arief, 2007).

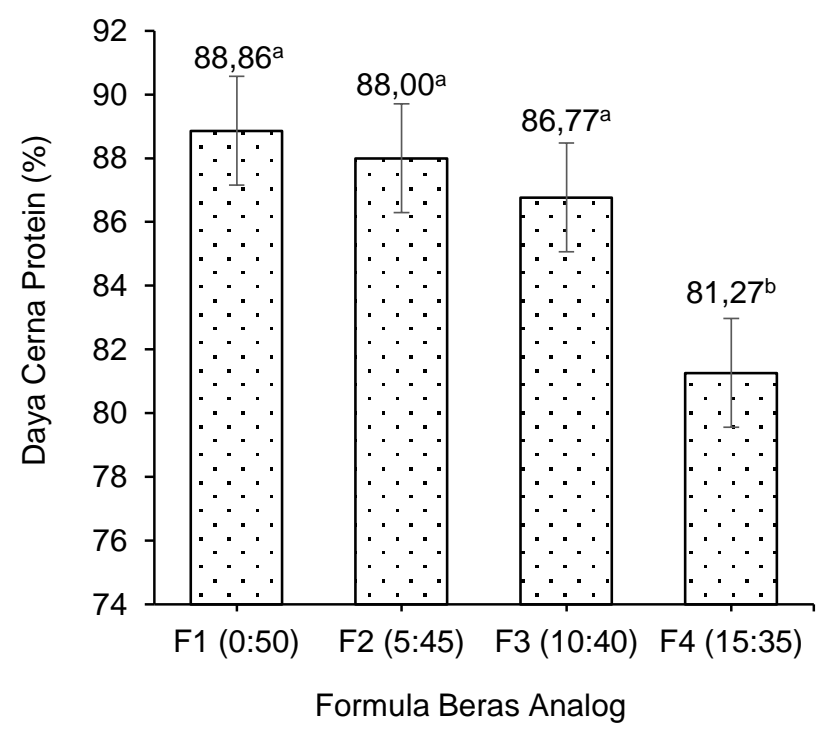

Gambar 2. Daya cerna protein beras analog multigrain

Kacang hijau dan kacang merah yang tidak dikupas kulit juga berpengaruh terhadap daya cerna protein karena kandungan serat (Tabel 3 ) dan zat antinutrisi yang tinggi (kacang hijau 5-9 mg/g asam fitat dan tanin, kacang merah $\pm 6 \mathrm{mg} / \mathrm{g}$ asam fitat dan tanin) (Yasmin et al., 2008). Kulit kacang hijau dan kacang merah menyumbang sekitar 0,30-0,50 mg/g zat antinutrisi (Mohamed et al., 2011). Perendaman mampu mengurangi zat antinutrisi, namun jumlah yang berkurang selama perendaman 12 jam berkisar antara $12-15 \%$ dan jumlah yang berkurang setelah ditambah proses pemanasan $95-97^{\circ} \mathrm{C}$ (suhu ekstruksi) adalah sekitar $65-70 \%$ (Shimelis dan Rakshit, 2007). Berdasarkan pernyataan tersebut, maka diasumsikan bahwa zat antinutrisi yang masih berperan sekitar $30-35 \%$. Kulit kacang merah dan kacang hijau yang tidak dihilangkan pada penelitian ini juga diduga berpengaruh terhadap tingginya kan- 
dungan serat. Kandungan serat yang tinggi berpotensi terhadap penurunan daya cerna protein (Arief, 2007).

Hasil penelitian ini mengindikasikan bahwa penambahan jewawut belum cukup efektif untuk meningkatkan kualitas protein, karena hanya mampu menaikkan kandungan protein $1-1,90 \%$ namun menurunkan $0,86-7,59 \%$ daya cerna protein. Penelitian tentang perlakuan awal bahan baku jewawut untuk tujuan menghilangkan tanin terkondensasi perlu dikaji lebih lanjut.

\section{Kandungan asam amino}

Hasil uji hedonik keseluruhan (overall) menunjukkan nasi analog F3 yang paling disukai panelis dan berbeda nyata dengan ketiga nasi dari formulasi lain. Berdasarkan hal tersebut, maka beras analog F3 dipilih menjadi sampel terbaik untuk dilakukan uji asam amino dan protein digestibilitycorrected amino acid score (PDCAAS).

Komposisi asam amino F3 disajikan pada Tabel 7. Asam amino isoleusin, leusin, fenilalanin dan tirosin, treonin, triptofan dan valin mengalami kenaikan jika dibandingkan dengan perhitungan awal F3 pada bahan baku mentah. Metionin dan sistein merupakan asam amino yang paling banyak mengalami penurunan setelah menjadi beras analog. Lisin juga menunjukkan sedikit penurunan yang dapat disebabkan oleh kerusakan asam amino akibat pemanasan beras analog selama proses ekstrusi dan pengeringan. Menurut Ito et al. (2019), hanya sekitar $30-80 \%$ asam amino bebas yang utuh pada bahan pangan setelah dimasak. Asam amino cenderung berkurang karena metabolisme, kelarutan dan destruksi.

Hasil penelitian Ito et al. (2019) dan Motta et al. (2019) yang memasak sayuran dan serealia juga menyatakan hal sama, yaitu beberapa asam amino meningkat kandungannya dan sebagian lainnya mengalami penurunan. Sayuran wortel kintoki dan kentang manis yang dimasak menurunkan semua asam amino kecuali leulisin, triptofan dan tirosin. Kandungan arginin, sistein, tirosin, histidin, metionin dan treonin menurun pada gandum kuda. Pada biji quinoa, hanya asam amino sulfur yang menunjukkan penurunan yang nyata. Asam amino sulfur (metionin dan sistein) merupakan asam amino paling sering mengalami penurunan pada pangan olahan matang karena sangat sensitif terhadap perlakuan panas.

Asam amino sulfur (metionin dan sistein) merupakan asam amino pembatas (Tabel 7). Asam amino ini mengalami penurunan yang sangat nyata jika dibandingkan dengan perhitungan awal komplementasi. Penurunan asam amino sulfur bisa disebabkan oleh reaksi oksidasi. Perlakuan panas pada penanganan bahan baku dan pengeringan ekstrudat dapat berpotensi mengurangi atau merusak asam amino sulfur terutama metionin. Metionin sangat mudah rusak dengan adanya suhu tinggi dan oksigen yang mengakibatkan terjadinya proses oksidasi (Lou et al., 2011).

Metionin dapat mengalami oksidasi dua elektron menjadi metionin sulfoksida atau oksidasi satu elektron menjadi kation radikal metionin. Kedua mekanisme reaksi tersebut memperoleh dukungan katalitik dari gugus tetangga, yang menstabilkan pusat reaksi karena kekurangan elektron (Lou et al., 2011) (Gambar 3). Atom S berikatan dengan satu atom $\mathrm{O}$ membentuk senyawa methionine sulfoxide residue dan atom $\mathrm{S}$ yang berikatan dengan dua atom $\mathrm{O}$ membentuk senyawa residu methionine sulfone.

Menurut Lou et al. (2011) hanya sekitar 15\% asam amino metionin yang rusak karena oksidasi. Penurunan lainnya dapat disebabkan oleh perlakuan awal bahan baku (perendaman pada kacang hijau dan kacang merah serta perebusan dan pengupasan kulit pada kedelai) dan perbedaan data kandungan asam amino acuan awal untuk perhitungan asam amino pada bahan baku untuk pembuatan produk.

Tabel 7. Asam amino esensial dan PDCAAS dari sampel beras analog formula 3

\begin{tabular}{|c|c|c|c|c|c|c|}
\hline Asam Amino & $\begin{array}{c}\text { Kalkulasi } \\
\text { Awal (mg/g } \\
\text { protein) }^{\mathrm{a}}\end{array}$ & $\begin{array}{l}\text { Hasil Uji (mg/g } \\
\text { protein) }^{b}\end{array}$ & $\begin{array}{l}\text { FAO 2013 } \\
(\mathrm{mg} / \mathrm{g} \\
\text { protein) }^{\mathrm{c}}\end{array}$ & $\begin{array}{c}\text { Skor Asam Amino } \\
(\%)^{d}\end{array}$ & $\begin{array}{l}\text { Daya } \\
\text { Cerna }^{\mathrm{e}}\end{array}$ & $\begin{array}{l}\text { PDCAAS } \\
(\%)^{\dagger}\end{array}$ \\
\hline Ile & 40 & 50 & 30 & 168,84 & & \\
\hline Leu & 98 & 103 & 61 & 169,26 & & \\
\hline Lys & 48 & 44 & 48 & 92,06 & & \\
\hline Met dan Cys & 31 & 9,77 & 23 & 42,48 (AAP) & 0,86 & 36,53 \\
\hline Phe dan Tyr & 83 & 133 & 41 & 326,30 & & \\
\hline Thr & 37 & 57 & 25 & 228,79 & & \\
\hline Trp & 10 & 10 & 6,6 & 152,05 & & \\
\hline Val & 48 & 56 & 40 & 140,33 & & \\
\hline
\end{tabular}

Keterangan: ${ }^{a}=$ Perkiraan awal komlementasi; ${ }^{b}=$ Hasil uji asam amino UPLC $;{ }^{c}=$ Rekomendasi asam amino dewasa FAO $(2013) ;{ }^{d}=$ Hasil $(b / c) \times 100 \%, \stackrel{e}{=}$ Daya cerna protein in vitro; $f=$ Hasil $(e \times f) ; A A P=$ Asam Amino Pembatas (asam amino terkecil) 


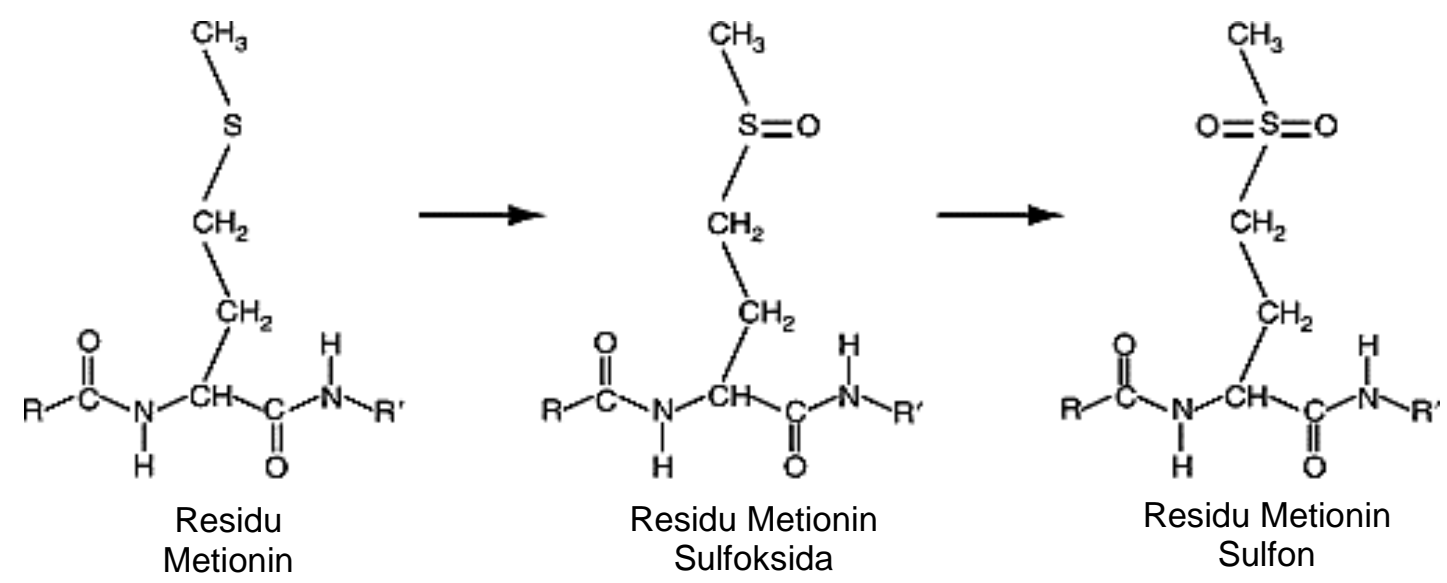

Gambar 3. Perubahan residu metionin (Lou et al., 2011)

Perbedaan data kandungan asam amino acuan awal untuk perhitungan dengan asam amino bahan baku untuk pembuatan produk diduga karena pengaruh dari perbedaan varietas, tempat tumbuh (lingkungan), dan perawatan tanaman (pemupukan dan unsur hara tanah). Arief (2007) menyatakan bahwa terdapat perbedaan yang nyata antara satu varietas jagung dengan varietas jagung lainnya, yaitu varietas srikandi putih memiliki asam amino sulfur (metionin dan sistein) $37,36 \mathrm{mg} / \mathrm{g}$ protein, srikandi kuning $30,70 \mathrm{mg} / \mathrm{g}$ protein, bisi dua 25,22 $\mathrm{mg} / \mathrm{g}$ protein dan lamuru $22,16 \mathrm{mg} / \mathrm{g}$ protein. Tirajoh et al. (2015) juga menyatakan bahwa kandungan asam amino sulfur pada jewawut berbeda tergantung pada tempat daerah tanamnya (lingkungan dan tanah). Jewawut hasil penelitian Boroojeni et al. (2011) pada foxtail jewawut $(0,54 \mathrm{~g} / 100 \mathrm{~g}$ sampel) berbeda dengan jewawut kuning papua $(0,21 \mathrm{~g} / 100$ $\mathrm{g}$ sampel) dan jewawut merah papua $(0,31 \mathrm{~g} / 100 \mathrm{~g}$ sampel). Saprudin et al. (2019) menunjukkan bahwa pemberian pupuk komersial Fe-kelat 250 ppm dan nano-magnetit $\left(\mathrm{Fe}_{3} \mathrm{O}_{4}\right) 25 \mathrm{ppm}$ pada tanaman jagung dapat meningkatkan kandungan asam amino esensial 33 dan 17\% dibandingkan kontrol (tanpa pemberian pupuk).

\section{Nilai protein digestibility-corrected amino acid score (PDCAAS)}

Telur dan susu merupakan produk dengan skor dan rasio asam amino esensial yang memenuhi standar dan juga memiliki daya cerna protein tinggi, sehingga ditetapkan sebagai produk dengan PDCAAS maksimum (100\%) (Hess et al., 2016). Protein nabati dianggap sebagai sumber protein tidak lengkap karena profil asam amino dan daya cerna yang relatif rendah jika dibandingkan dengan produk turunan hewani (Shaheen et al., 2016).

Nilai PDCAA dari F3 adalah $36,53 \%$, yang lebih rendah dibandingkan dengan nilai PDCAAS telur dan susu acuan. Menurut Joye (2019), PDCAAS nabati relatif rendah, terutama setelah proses pengolahan karena sifat asam amino yang cenderung bereaksi dengan lingkungannya (hidrofilik, hidrofobik, asam, basa dan mudah teroksidasi). Penelitian Avilés-Gaxiola et al. (2017) dan Sakinah et al. (2019) juga melaporkan penurunan kandungan asam amino hidrofilik akibat larut dalam air setelah perlakuan perendaman pada kedelai dan biji kelor. Nilai PDCAAS yang rendah pada produk ini (Tabel 7) dipengaruhi oleh kandungan asam amino pembatas (metionin dan sistein).

\section{KESIMPULAN}

Beras analog yang dibuat dari campuran kacang merah, kacang hijau, kedelai, jagung, wijen dan jewawut memiliki kandungan protein berkisar $18,19-19,09 \%$ yang menyumbang 16,61-18,62 energi sehingga memenuhi klaim sebagai pangan sumber protein berdasarkan Peraturan EU (2012). Beras analog yang dihasilkan memiliki karbohidrat yang lebih rendah dibandingkan beras padi. Beras analog memiliki mutu protein yang sangat baik dengan daya cerna protein yang tinggi yaitu $\mathrm{F} 1(88,86 \pm 0,17 \%), \mathrm{F} 2$ $(88,00 \pm 0,23 \%)$, F3 $(86,77 \pm 0,72 \%)$ dan F4 $(81,27 \pm$ $1,38 \%$ ). Formula terbaik berdasarkan uji hedonik adalah beras analog formula 3 yang menggunakan $10 \%$ jewawut dan $40 \%$ jagung, beras analog ini memiliki skor asam amino $42,48 \%$ dan nilai PDCAAS $36,53 \%$.

\section{DAFTAR PUSTAKA}

Almeida CC, Monteiro MLG, da Costa-Lima BRC, Alvares TS, Conte-Junior CA. 2015. In vitro digestibility of commercial whey protein supple- 
ment. LWT-Food Sci Technol 61: 7-11. DOI: 10.1016/j.lwt.2014.11.038.

Amadou I, Gounga ME, Le GW. 2013. Millets: Nutritional composition, some health benefits and processing. Emir J Food Agric 25: 501-508. DOI: 10.9755/ejfa.v25i7.12045.

Annor GA, Tyl C, Marcone M, Ragaee S, Marti A. 2017. Why do millets have slower starch and protein digestibility than other cereals?. Trends Food Sci Tech 66: 73-83. DOI: 10.1016/j.tifs. 2017.05.012.

Anindita TH, Kusnandar F, Budijanto S. 2020. Sifat fisikokimia beras analog jagung dengan penambahan kacang kedelai varietas grobogan dan detam-1. J Teknol Industri Pangan 31: 2937. DOI: 10.6066/jtip.2020.31.1.29.

Anitha S, Govindaraj M, Kane-Potaka J. 2019. Balanced amino acid and higher micronutrients in millets complements legumes for improved human dietary nutrition. Cereal Chem 97: 7484. DOI: 10.1002/cche.10227.

[AOAC] Association of Official Analytical Chemist. 2012. Official Methods of Analysis of the Association of Analytical Chemist. Arlington: The Association of Official Analytical Chemist, Inc.

Arief RW. 2007. Analisis kualitas relatif protein jagung secara in vivo dengan metode PDCAAS. J Pengkajian Pengembangan Teknologi Pertanian 10: 95-104.

Astawan M, Wresdiyati T, Saragih AM. 2015. Evaluasi mutu protein tepung tempe dan tepung kedelai rebus pada tikus percobaan. J Mutu Pangan 2: 11-17.

Avilés-Gaxiola S, Chuck-Hernández C, Saldívar SOS. 2017. Inactivation methods of trypsin inhibitor in legumes - a review. J Food Sci 83: 17-29. DOI: 10.1111/1750-3841.13985.

Behzadfar E, Ansari M, Konaganti VK, Hatzikiriakos SG. 2015. Extrudate swell of HDPE melts: I. Experimental. J Non-Newton Fluid 225: 86-93. DOI: 10.1016/j.jnnfm.2015.07.008.

Boroojeni FG, Samie AH, Edriss MA, Khorvash M, Sadeghi G, Van Kessel A, Zentek J. 2011. Replacement of corn in the diet of broiler chickens using foxtail millet produced by 2 different cultivation strategies. Poult Sci 90: 2817-2827. DOI: 10.3382/ps.2011-01647.

Budi FS, Hariyadi P, Budijanto S, Syah D. 2017. Kristalinitas dan kekerasan beras analog yang dihasilkan dari proses ekstrusi panas tepung jagung. J Teknol Industri Pangan 22: 263-274. DOI: 10.6066/jtip.2017.28.1.46.
Budijanto S, Yuliyanti. 2012. Studi persiapan tepung sorgum (Sorghum bicolor L. Moench) dan aplikasinya pada pembuatan beras analog. J Teknologi Pertanian 13: 177-186.

Budijanto S, Andri YI, Faridah DN, Noviasari S. 2013. Karakterisasi kimia dan efek hipoglikemik beras analog berbahan dasar jagung, sorgum, dan sagu aren. Agritech 37: 402-409. DOI: 10.22146/agritech.10383.

Busuttil-Griffin F, Shoemake C, Attard E, Azzopardi LM. 2015. Crude fibre determination of Malva sylvestris $L$. and evaluation of its faecal bulking and laxative properties in rats. Int $\mathrm{J}$ Biol 7: 1-8. DOI: 10.5539/ijb.v7n4p1.

Di Girolamo FG, Situlin R, Fiotti N, Tence M, De Colle P, Mearelli F, Minetto MA, Ghigo E, Pagani M, Lucini D, Pigozzi F, Portincasa $P$, Toigo G, Biolo G. 2017. Higher protein intake is associated with improved muscle strength in elite senior athletes. Nutr 42: 82-86. DOI: 10.10 16/j.nut.2017.05.003.

[EU] European Commission. 2012. Amending Regulation (EC) No 1924/2006 with regard to the list of nutrition claims. Official Journal of the European Union L 310: 36-37.

[FAO] Food and Agriculture Organization. 1981. Amino-acid content of foods and biological data on proteins. http://www.fao.org/3/AC854T/AC85 4T00.htm\#TOC [04 Juni 2019].

[FAO] Food and Agriculture Organization. 2013. Dietary Protein Quality Evaluation in Human Nutrition. Report of an FAO Expert Consultation. Auckland, 31 March- 2 April 2011.

Fauziyah A, Marliyati SA, Kustiyah L. 2017. Subtitusi tepung kacang merah meningkatkan kandungan gizi, serat pangan, dan kapasitas antioksidan beras analog sorgum. J Gizi Pangan 12: 147-152. DOI: 10.25182/jgp.2017.12.2.147152.

Fitriani AAN, Astuti N. 2013. Pengaruh proporsi tepung jagung dan mocaf terhadap mutu "Jamof Rice" instan ditinjau dari sifat organoleptik. J Boga Gizi 2: 34-43.

Gehring J, Gaudichon C, Even PC. 2020. Food intake control and body weight regulation by dietary protein. Cahiers de Nutrition et de Diététique 55: e1-e8. DOI: 10.1016/j.cnd.2020. 10.001.

Hess J, Slavin J. 2016. Defining "protein" foods. J Nutr Today 51: 117-120. DOI: 10.1097/NT.0000 000000000157. 
Impa SM, Perumal R, Bean SR, John Sunoj VS, Jagadish SVK. 2019. Water deficit and heat stress induced alterations in grain physicochemical characteristics and micronutrient composition in field grown grain sorghum. J Cereal Sci 86: 124-131. DOI: 10.1016/j.jcs.2019.01. 013.

Ito H, Kikuzaki H, Ueno H. 2019. Effect of cooking methods on free amino acid contents in vegetables. J Nutr Sci Vitaminol 65: 264-271. DOI: $10.3177 /$ jnsv.65.264.

Joye I. 2019. Protein digestibility of cereal products. Foods 8: 199-212. DOI: 10.3390/foods8060199.

Kanetro B, Pujimulyani D, Luwihana S, Sahrah A. 2017. Karakteristik beras analog berindeks glisemik rendah dari oyek dengan penambahan berbagai jenis kacang-kacangan. Agritech 37: 256-262. DOI: 10.22146/agritech.31538.

Karouw S. 2016. Produk ekstrusi berbahan tepung jagung, tepung beras dan konsentrat protein krim kelapa. J Buletin Palma 13: 66-73 DOI: org/10.21082/bp.v13n2.2012.66-73.

[Kemenkes RI] Kementerian Kesehatan Republik Indonesia. 2018. Tabel Komposisi Pangan Indonesia. Kementerian Kesehatan Republik Indonesia, Jakarta.

Kharat S, Medina-Meza IG, Kowalski RJ, Hosamani A, Ramachandra CT, Hiregoudar S, Ganjyal GM. 2019. Extrusion processing characteristics of whole grain flours of select major millets (foxtail, finger, and pearl). Food Bioprod Process 114: 60-71. DOI: 10.1016/j.fbp.2018. 07.002

Lee JH, Cho AR, Hong JY, Park DJ, Lim ST. 2012. Physical properties of wheat flour composites dry-coated with microparticulated soybean hulls and rice flour and their use for low-fat doughnut preparation. J Cereal Sci 56: 636-643. DOI: 10.1016/j.jcs.2012.08.011.

Lieberman HR, Fulgoni VL, Agarwal S, Pasiakos SM, Berryman CE. 2020. Protein intake is more stable than carbohydrate or fat intake across various US demographic groups and international populations. Am J Clin Nutr 112: 180-186. DOI: 10.1093/ajcn/nqaa044.

Lou Y, Matejic T, Ng CK, Nunnally B, Porter T, Raso S, Rouse J, Shang T, Steckert J. 2011. 8Characterization and analysis of biopharmaceutical proteins. Separ Sci Technol 10: 283359. DOI: 10.1016/B978-0-12-375680-0.000085.

Meilgaard MC, Civille GV, Carr BT. 1999. Sensory Evaluation Techniques (Third edition). 195-216. CRC Press, Boca Raton, US. DOI: 10.1201/97 81439832271.
Mohamed R, Abou-Arab EA, Gibriel AY, Rasmy $\mathrm{NMH}$, Abu SFM. 2011. Effect of legume processing treatments individually or in combination on their phytic acid content. Afr J Food Sci Technol 2: 36-46.

Motta C, Castanheira I, Gonzales GB, Delgado I, Torres D, Santos M, Matos AS. 2018. Impact of cooking methods and malting on amino acids content in amaranth, buckwheat and quinoa. J Food Compos Anal 76: 58-65 DOI: 10.101 6/j.jfca.2018.10.001.

Noviasari S, Kusnandar F, Budijanto S. 2013. Pengembangan beras analog dengan memanfaatkan jagung putih. J Teknol Industri Pangan 24: 194-201. DOI: 10.6066/jtip.2013.24.2.194.

Noviasari S, Kusnandar F, Setiyono A, Budijanto S. 2015. Beras analog sebagai pangan fungsional dengan indeks glikemik rendah. J Gizi Pangan 10: 225-232.

Patil KB, Chimmad BV, Itagi S. 2015. Glycemic index and quality evaluation of little millet (Panicum miliare) flakes with enhanced shelf life. J Food Sci Technol 52: 6078-6082. DOI: 10.1007/s13197-014-1663-5.

Rincón-Londoño N, Vega-Rojas LJ, ContrerasPadilla M, Acosta-Osorio AA, Rodríguez-García ME. 2016. Analysis of the pasting profile in corn starch: Structural, morphological, and thermal transformations. Int J Biol Macromol 91: 106114. DOI: 10.1016/j.jibiomac.2016.05.070.

Sakinah N, Prangdimurti E, Palupi NS. 2019. Kandungan gizi dan mutu protein tepung biji kelor terfementasi. J Teknol Industri Pangan 30: 152160. DOI: 10.6066/jtip.2019.30.2.152.

Saprudin D, Palupi CA, Rohaeti E. 2019. Evaluasi pemberian unsur hara besi pada kandungan asam amino dan mineral dalam biji jagung. $J$ Kimia Riset 4: 49-61. DOI: 10.20473/jkr.v4i1. 11774.

[SIG] Saraswanti Indo Genetech. 2013. Instrumen kerja pengujian asam amino metode UPLC. No. instruksi 18-5-17/MU/SMM-SIG. Tanggal terbit 19 Agustus 2013.

Shaheen N, Islam S, Munmun S, Mohiduzzaman Md, Longvah T. 2016. Amino acid profiles and digestible indispensable amino acid scores of proteins from the prioritized key foods in Bangladesh. Food Chem 213: 83-89. DOI: 10.1016/j.foodchem.2016.06.057.

Shimelis EA, Rakshit SK. 2007. Effect of processing on antinutrients and in vitro protein digestibility of kidney bean (Phaseolus vulgaris L.) varieties grown in East Africa. Food Chem 103: 161-172. DOI: 10.1016/j.foodchem.2006.08.005. 
Suarni, Firmansyah IU, Aqil M. 2013. Keragaman mutu pati beberapa varietas jagung. J Penelitian Pertanian Tanaman Pangan 32: 50-56.

Sukarno, Kushandita N, Budijanto S. 2020. Karakterisasi sifat fisikokimia sereal berbasis tepung beras merah pecah kulit. J IImu Pertanian Indonesia 25: 81-86. DOI: 10.18343/jipi.25.1. 81.

Tirajoh S. 2015. Pemanfaatan jewawut (Setaria italica) asal Papua sebagai bahan pakan pengganti jagung. WARTAZOA 25: 117-124 DOI: 10.14334/wartazoa.v25i3.1156.
Wibawa IS, Argo BD, Hendrawan Y. 2020. Penentuan parameter teknis ekspansi beras (Oryza sativa) pada beberapa variasi lama pemasakan dan jumlah air. J Keteknikan Pertanian Tropis dan Biosistem 3: 154-162.

Yasmin A, Zeb A, Khalil AW, Paracha GMD, Khattak AB. 2008. Effect of Processing on Antinutritional Factors of Red Kidney Bean (Phaseolus vulgaris) Grains. Food Bioprocess Tech 1: 415-419. DOI: 10.1007/s11947-0080125-3. 